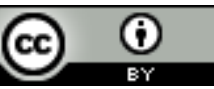

LECTIO PRAECURSORIA

Juho Saksholm

\title{
Reform, Revolution, Riot? Transnational Nordic Sixties in the Radical Press, c.1958-1968
}

Bill Clinton, the first American president who belonged to the so-called baby boomer generation, once reflected on his own youth by saying:

'If you look back on the 1960s and on balance, you think there was more good than harm, then you're probably a Democrat. If you think there was more barm than good, you're probably a Republican."

Whether we now live in a world where the sixties is treated with newly found appreciation or with even deeper resentment remains to be seen.

But this quote begs the question: Who "owns" the Sixties? Who has the power to define its essence? Many have tried to use the Sixties and its legacy to explain current political and social phenomena. Let us take couple of concrete examples:

After his resignation, the former pope Benedict XVI wrote an essay to a German catholic paper Klerusblatt, aiming to explain the reasons for the paedophilia scandal that had devastated the catholic church. The former pope directly associated the heinous crimes of the catholic clergy and the church with the Sixties and the emergence of sexual liberation and relativism that, according to the former Pope, caused moral decadence in all corners of the society including the catholic church. ${ }^{2}$ This is certainly not a unique statement. Rather, it follows an established conservative narrative where family values, national pride, and human decency itself have been bit by bit ruined by relativist ideas endorsed by Sixties radical activists.

Just this week, those following the Finnish media could read an opinion piece by Jari Ehrnrooth, one of the leading culturally conservative public intellectuals in this country. In his text, Ehrnrooth accused Sixties New left of propagating Marxist and relativist ideas. Ehrnrooth asserted his readers that not only are these sixties ideas responsible for the politicization of everyday lives and the wrecking of civilized public debate, they have also led to other grave things, among them the loss of western leadership in global politics. Following this logic, it is only natural that Ehrnrooth saw the presidency of Donald J. Trump as an outcome of the actions of Sixties New Left. This certainly is an original idea, albeit one that necessitates some mental gymnastics.

Comparisons between our own time and the Sixties have not been the exclusive right of conservative commentators. For many on the left, the Sixties has served as a mythological reference point for antiauthoritarian political action. Many subsequent social movements have directly paid tribute to Sixties movements, and treated famous Sixties activists with particular reverence. This is in many ways understandable and even justifiable: many of the issues that emerged through Sixties activism have remained at the centre of contemporary politics. Freedom of speech limitations, racism, and access to 
public space are all still highly relevant political issues, even if they are now problematized by different social movements than they were during the Sixties.

Yet, authors that emphasize these continuities often pay little attention to proving their existence. A recent example: many feature-length articles discussing the birth of the Black Lives Matter -movement repeatedly begin their analysis with the sixties civil rights movement and its successes, failures and inner conflicts. While this certainly puts Black Lives Matter into an understandable historical continuum, it also downplays inner conflicts that often directly contribute to the establishment of a new social movement. Unless someone actually studies how the movement itself reflects on these historical continuities, comparisons to past movements tell perhaps more about the reporter than about the movement itself.

So, does the Sixties really mark the beginning of our contemporary cultural wars, that is, the politicization of questions that traditionally have been considered to be in the sphere of individual morality? Not everyone would agree with this statement. Contemporary sociologists would probably point to the power of social media and the uncontrolled online platforms that can inspire new kinds of political action. Scholars of interwar left might remind us of the fact that there were intellectuals and groups resisting authoritarian tendencies already during the 1930s. And the historians of the French third republic are always ready to remind us of the seminal role of the Dreyfuss affair as the original cultural conflict between conservatives and radicals. It seems then, that moral polarization is not a new thing at all; rather, it is an integral feature of our political system, and discussions around the matter keep appearing in different historical and political contexts. In this light, Sixties activism seems to be part of a long tradition rather than a moment of fundamental change.

Yet, one can definitely say that these examples of the political uses of the Sixties demonstrate that that particular decade has cultural significance. The things our popular culture, media, and scholarly works associate with the Sixties clearly resonate with some fundamental social and cultural need.

If we want to take a historical view of the Sixties, then we need to decide the historical agents that could enlighten us on the particularities of this period. In other words, we must ask Who are the protagonists of this story?

Youth is perhaps the most important buzzword of the Sixties, and an integral feature in the way the decade has been defined through emerging youth culture and politics. As Professor Richard Vinen has noted, not all student leaders were students at all, nor were all young radicals that young. ${ }^{3}$ But this had little significance for the contemporaries, who cherished the notion that the youth, not tainted by the experiences of the war or the holocaust, could lead the world to a new, brighter future.

The political association with youth was certainly significant, and it opened up the future to new political currents. At the same time, the people who had personal experience from the war were still present and active members of the society. Many of those with experience from the frontlines of the war were in their forties, which, at least from my personal perspective, is not that old at all. Many studies conducted during the 1990s tried to push forward the argument that Sixties radicalism was not a political but rather a generational phenomenon. This explanation does not take into account the Politics of age, as Holly Scott has done in her insightful book "younger than that now: the politics of age in the 1960s". Furthermore, generational theories do not take into consideration the fact that arguments associating young age with radicalism were present in contemporary sixties debates. Instead of assuming a natural divide between generations, we should look into the way these divisions were created and maintained, and what political significance they had.

One conundrum in explaining the birth of anti-authoritarian social movements is to indicate who originally were responsible for their establishment. Since modern social movements in general and those of the Sixties in particular were highly suspicious of organizational structures, spontaneity was often the 
most priced quality of political action. Emphasising the spontaneous nature of protesting was a deliberate choice, meant to legitimize social movements as genuine political actors that enjoyed popular support.

One alternative to the explanation of radicalism as an organic product of social conditions has been to focus on how Sixties movements were profoundly inspired by so-called intellectuals. While Herbert Marcuse was certainly an important philosopher and definitely one of the few if not the only Marxists featured in the pages of the Playboy magazine, star philosophers like Marcuse offer a bit too convenient of an explanation for the emergence of new forms of political action. Studying the reception of highbrow ideas is notoriously hard and should always be empirically verified. Thus, in this thesis I propose a decidedly more grassroots approach to the social movements of the sixties. Instead of assuming organic or intellectual roots for these movements, this thesis approaches them as entities created by a rhizomatic network of political activism that constanly reacted and readjusted itself to better take advantage of political currents and opportunities available in local contexts.

In addition to the complexity of defining who made the sixties, there is also the dilemma of pointing out Where it actually happened? Paris, Berlin, and Berkeley standard reference points that have dominated discussions. The protests of 1968 were indeed a global phenomenon. While many have tried to lump these protests together as one, global and unified movement, this is not an adequate explanation for a historian. Therefore, in an effort to see how activists themselves saw the global dimensions of their protest movement, we need to look how these global dimensions played out in specific local contexts.

Finland and Sweden, two neutral Nordic countries are the focal point of this study. Hundreds of years of shared history and all the often-repeated institutional similarities are only one perspective to the distinct Nordicness of these two countries. Many structures of political discourse are astonishingly similar when one takes into consideration the fact that the two majority languages spoken are not structurally related.

From the Finnish perspective at least, comparisons between these two neighbours are almost an everyday phenomena. The way in which we compare ourselves to our bigger, more prosperous and progressive neighbour is an important cultural trope. It sells plenty of tabloid papers, books, and even movies. Whether the Swedes are actually even interested in our country is a matter of constant debate. Comparisons to Sweden are also a mainstay of political discourse. Here, Sweden serves a double role: for progressives, it is the haven of tolerance and modernity, for conservatives a warning example on the way too much ambition and globalism can ruin important national institutions and traditions. While these perspectives are polar opposites, both treat Sweden as a sign of our future. Sweden seems to dominate our horizon of expectations, to use Reinhart Koselleck's famous concept.

In the Sixties context, the peculiar position of the Nordics offered both a political resource but also a dilemma. Nordic activists were in many ways in the peripheries of European social movement activism; as this thesis shows, establishing connections and networks with continental European radical movements was slow and laborious, and often led to disappointment rather than inspiration. Yet, the distinctive "third way" of Nordic societies was, for many contemporaries at least, a shining example of their relative progressivism when compared to their continental peers that had to deal with conservative institutions such as the Catholic Church or Christian democratic parties. It is important to note that these divisions are not a creation of scholarly analysis: they are a key feature of contemporary discussions and experiences. A scholar should be particularly sensitive to these historical comparisons and the political structures and narratives they are built on. Maybe analysing comparisons done by historical actors themselves could even become a future way of doing comparative history. 
Now, when this lecture is turning towards its end, is perhaps the right moment to ask: what is the Sixties? Is it an historical period or phenomenon? If it is an era, when was it? And if it was a phenomena, what did it consist of?

In terms of chronology, these questions might seem naïve and obvious. Yet, Arthur Marwick's magnum opus The Sixties, for example, covers a period from 1958 to 1974'; roughly a similar periodization is also in use in the journal The Sixties. many contemporaries have different opinions about this: for them, these framings that emphasize "the long sixties" bring forward the uneasy question of what was their part in creating the dogmatic and even violent political movements of 1970s. Finnish memoirs, for example, often offer a more concise version of the chronology: some suggest that "The Finnish Sixties" begun in around 1963, while others maintain that it lasted for only two years between 1966 and 1968. These different periodizations are fascinating and tell a lot about the way in which emphasis on different aspects of the sixties affect the way it is defined as a historical period.

If, on the other hand, we focus on the Sixties as a phenomenon, we still face a similar dilemma of defining it. While many documentaries, news stories, and book covers have focused on the public protesting, riots and cultural happenings of 1968, in many contexts the radicalism of the sixties was a more bookish affair. Even Timothy Scott Brown, whose studies focus on the famously dramatic West German protests, has called the Sixties "a revolt of Texts". Admittedly, a radical with a banner makes a more intriguing book cover when compared to a one armed with just a typewriter.

Still, I am confident that this thesis demonstrates that public debates did matter. They did not only reflect changes happening inside the radical movement, but were also instrumental in initiating many of the political processes. As the famous Wittgenstein quote says, "The limits of my language mean the limits of my world." By taking the language used by sixties agents seriously and approaching it from a transnational perspective, this thesis also attempts to push forward new methodological approaches. Many scholars have aspired to combine empirical history research and its focus on primary sources with the demands of expanding the focus beyond the nation state. This thesis offers one possible answer to this question.

FM Jubo Saksholmin Suomen historian väitöskirja "Reform, Revolution, Riot? Transnational Nordic Sixties in the radical press, c. 1958-1968” tarkastettiin Jyväskylän yliopistossa 5.11.2020. Vastaväittäjänä toimi professori GerdRainer Horn (Sciences Po, Ranska) ja kustoksena yliopistotutkija, dosentti, FT Pïa Einonen (Jyuäskylän yliopisto).

Julkaisun pysyvä osoite on http:/ / urn.fi/URN:ISBN:978-951-39-8374-1 
${ }^{1}$ https://www.independent.co.uk/news/world/americas/first-night-clinton-takes-to-the-stage-for-the-ultimate-sell731119.html, viitattu 20.11.2020

2 https://de.catholicnewsagency.com/story/die-kirche-und-der-skandal-des-sexuellen-missbrauchs-von-papst-benedikt-xvi4498, viitattu 20.11.2020

${ }^{3}$ Vinen, Richard. The Long '68: Radical Protest and Its Enemies. London: Allen Lane, 2018.

${ }^{4}$ Marwick, Arthur. The Sixties: Cultural Revolution in Britain, France, Italy, and the United States, C.1958-c.1974. Oxford ; New York: Oxford University Press, 1998.

${ }^{5}$ Brown, Timothy Scott. West Germany and the Global Sixties: The Antiauthoritarian Revolt, 1962-1978. Cambridge [England]: Cambridge University Press, 2013. 